\title{
Radio, Internet, Music and Mobile
}

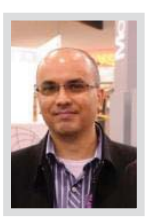

Moderator: Tomaz Alonso

Technical Manager / Globo Radio System

Internet landscape in Brazil: Radio, Podcasting and Mobile Speaker: Luciana Burger

Managing Director / comScore Brasil

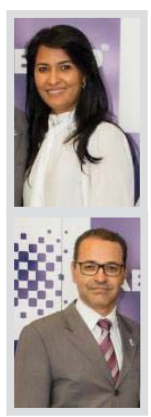

Palavra de ordem aos radiodifusores: interatividade mobile para fidelizar o seu ouvinte

Speaker: Malu Villela

Diretora Comercial / Rádio Tradição / Access Informática

Speaker: Márcio Villela

Secretário de Estado da Comunicação Social no Paraná

Musical Radios \& streaming services

Speaker: Jonas Vilandez

Manager / Rádio BHfm 


\section{Radio}

\section{RADIO, INTERNET, MUSIC AND MOBILE}

\section{Moderator: Tomaz Alonso}

Technical Manager / Sistema Globo de Rádio

This panel will discuss the radio in the Internet, the challenges in an unstable competitive environment in which music streaming services are growing rapidly in audience and its presence in smartphones is a premise. There will be 3 presentations. The first will show an overview of the Internet in Brazil and in the World, with emphasis on aspects of mobility and audio media. The second will discuss the positioning of musical radios before the online music services. The third will discuss the radio presence in mobile, particularly the 'Mobilize-se' app design for radios from ABERT.

- Internet landscape in Brazil: Radio, Podcasting and Mobile Speaker: Luciana Burger Managing Director / comScore Brasil

Presentation of a synthesized view regarding the comScore studies: - "Brazil Digital Future in Focus";

- "Mobile and Multi + Platform Scenario in Brazil."

- Watchword to broadcasters: mobile interactivity to retain your listener Speaker: Malu Villela Commercial director / Rádio Tradição / Access Informática Speaker: Márcio Villela Secretary of State for Social Communication in Paraná

- Musical Radios \& streaming services Speaker: Jonas Vilandez Gerente / Rádio BHfm 

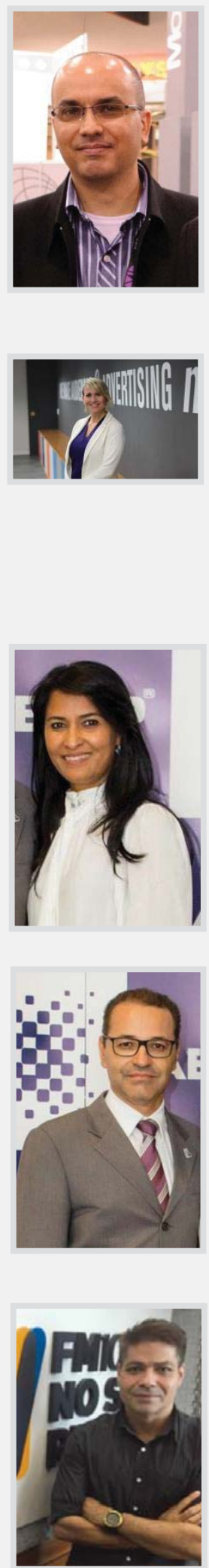

\section{TOMAZ ALONSO}

Technical Manager - Globo Radio System

He manages operational audio and video production processes, while also developing and heading up new technical projects based on his media market expertise.

Tomaz Alonso has a degree in electrical engineering, with specialization in electronics, from the Mackenzie Presbyterian and the São Judas Tadeu Universities, in addition to having also attended management and leadership courses at the Dom Cabral Foundation. With 29 years of experience in broadcasting and industry, he has worked for companies such as "Jornal O Estado de São Paulo" (Rádio Estadão), Ultrasolda (automotive electronics), Mitsubishi and Philips (consumer electronics division). Since 2007, he has held the position of Technical Manager in the Radio Globo System, working on transmission projects, operations, external events and administration of the studio's stations in São Paulo.

\section{LUCIANA BURGER}

Managing Director, Brazil / comScore Inc.

Luciana Burger is a Digital Marketing professional with extensive experience in sales and operations acquired on the main portals of Latin America. In 2012, Luciana joined Terra Networks (Telefónica) as Director of Global Operations. Before joining Terra, she dedicated seven years of her career at Microsoft in on-line advertising (2005-2012), and was responsible for Advertising Sales at Grupo Clarín (2003-2005). In 2015, she headed up the executive board of comScore Brazil, commencing a new phase in her career. With a solid academic background, she has pursued a parallel career as a university professor over the last 17 years, and she lectures on MBA courses in Digital Marketing at the Superior School of Advertising and Marketing (ESPM).

\section{MALU VILLELA}

Sales Director - Rádio Tradição / Access Informática

Sales Director at Rádio Tradição and Access Informática, a supplier of systems to radio broadcasters, with 28 years' experience in the communication segment, specializing in Management, Automation and Applications systems, with the largest base of management and mobile applications management systems installed in radio stations in Brazil and Mexico. She has a specialization is Business Management and 23 years' experience in administration and sales management. She was in charge of setting up and bringing on stream a branch of the company in Mexico so as to break into the market there.

\section{MÁRCIO VILELLA}

Secretary of State - Secretary of State for Social Communication in Paraná $\mathrm{He}$ has been involved for over 25 years in the broadcasting industry, with two consecutive terms of office - from 2012 to 2015 - as president of The Broadcasters' Association of Paraná (AERP). During this period, he advocated for the development and strengthening of the milieu, which brought him the title of Communication Personality of Paraná, awarded by the Association of Sales and Marketing Managers of Brazil (ADVB-PR) in 2015. He has a Degree in Civil Engineering from the Pontifical Catholic University of Paraná (PUC-PR) and an MBA in Management from the Getúlio Vargas Foundation in Rio de Janeiro (FGV-RJ). He held the post of Municipal Planning Secretary in Araucária (in the metropolitan region of Curitiba) in 2015, and has acquired extensive experience in management focused on technology and innovation.

\section{JONAS VILANDEZ \\ Gerente / Rádio BHfm}

